\section{THE "SUMMER TIME" BILL.}

" $\mathrm{HE}$ main provisions of the "Summer Time" Bill, which was introduced in the House of Commons on May 9 by the Home Secretary, Mr. Herbert Samuel, and was read a second time in the House of Lords on May 16, are as follows :-

(I) During a prescribed period the local time in Great Britain is to be one hour in advance of Greenwich mean time.

(2) The prescribed period this year is from two o'clock in the morning Greenwich mean time on Sunday, the twenty-first day of May, until two o'clock in the morning Greenwich mean time on Sunday, the first day of October, and during the continuance of the present war the Act can be declared by Order in Council to be in force for any prescribed period.

(3) During the prescribed period any expression of time in any Act of Parliament, Order in Council, order, regulation, rule, or by-law, or in any deed, time-table, notice, advertisement, or other document, is to mean "Summer Time."

(4) The Act is to apply to Ireland as to Great Britain, with the substitution, however, of references to Dublin mean time for references to Greenwich mean time.

(5) Greenwich mean time is to be maintained as hitherto, for purposes of astronomy or navigation.

No particular time is prescribed for meteorologists, who are left to decide for themselves whether to record their observations at the same hour G.M.T. throughout the year, or to adopt the Summer Time for five months and G.M.T. for the remainder. A like difficulty arises with self-registering meteorological instruments, which are used to record continuously day and night. Either the instruments are to be an hour wrong in the summer, or meteorologists are to use a time-system different from that of the general public. For example, the five thousand voluntary observers connected with the British Rainfall Organisation record their readings at 9 a.m., which is to be ro a.m. Summer Time. Dr. H. R. Mill, director of the Organisation, has had to announce to his observers that the readings should be taken, if possible, at 9 a.m. G.M.T., as hitherto, or a note should be made on each page of the observation book if the readings are taken at 9 a.m. Summer Time. Anyone who is concerned with the preservation of records for long series of years must contemplate with blank dismay the dual system about to be introduced.

Lighting-up times, as was stated in last week's Nature, depend upon local times of sunset, and are therefore based upon Greenwich mean time, with differences for latitude and longitude. The Law Journal points out that since sunrise and sunset always mean in law the exact moment at which the sun rises or sets at any particular place, the obligation to light up vehicles an hour after sunset-an interval which is reduced to half an hour during the war-is not affected by the Summer Time Bill. The law will thus maintain local time for many of the statutes in which time is mentioned, and this, for nearly all places in Great Britain and Ireland, will be later than Greenwich time, not an hour earlier, as the Summer Time Bill prescribes. As the tides, sunrise and sunset, lunar phases, and like occurrences belong to navigation and astronomy, they will continue to be tabulated in advance in Greenwich time; but all public clocks are to show mid-European time.

The economic and social advantages claimed for this introduction of confusion into an orderly system of time-reckoning remain to be seen; but whatever they are there can be no question that the scheme of a fluctuating time-standard has no natural basis. It is the duty of a scientific journal to point out the objections to the scheme, even though it stands alone, and, in the opinion of the public, may represent what is contemptuously termed scientific theory as something apart from the practical needs of life. The diffculties are not appreciated by our legislators, and few writers in the public Press have shown any intelligent understanding of them, while scientific interests have been completely disregarded. The only satisfaction to be derived from this childish method of promoting the increased use of daylight is that the measure is limited to the period of the war.

\section{PURIFICATION OF COAL-GAS.}

PROF. FRANK CLOWES read a paper before the Society of Chemical Industry on May I dealing with the past and present of the sulphur impurity in coal-gas. He recalled that the higher temperature carbonisation arising from the displacement of iron by fireclay retorts had resulted in an increased amount of sulphur coming into the gas, not only in the form of hydrogen sulphide, but more noticeably as sulphur compounds of an organic nature. Purification by iron oxide is sufficient to remove sulphuretted hydrogen, but the removal of these organic compounds is much more difficult. "Sulphided lime," prepared by passing coal-gas containing hydrogen sulphide, but free from carbon dioxide, over freshly slaked lime, was in common use for the purpose, but its action was so uncertain that a Board of Trade Committee which inquired into the subject came to the conclusion that any statutory requirement that the sulphur impurities should be removed to such an extent as to demand the use of lime ought to be discontinued. The detrimental physiological effect and very slight, or non-existent, disinfectant value of the sulphurous products of combustion of coal-gas were, however, plainly indicated by Dr. Haldane, and experimental results were also brought forward which proved that these sulphurous products caused leather to rot and ultimately to crumble, and that some fabrics were similarly affected.

Dr. C. Carpenter and his collaborators have advanced matters by working out on the large scale a practical method of removing carbon bisulphide by passing the gas at a temperature of about $45^{\circ} \mathrm{C}^{1}$ (the author gives the temperature $450^{\circ} \mathrm{F}$., presumably a misprint) over fireclay surfaces impregnated with reduced nickel. The hydrogen sulphide formed is removed by subsequent exposure of the coal-gas to iron oxide, and the carbon deposited on the fireclay-nickel surface is burned off; the sulphur of the coal-gas is so reduced to about 8 grains per Ioo cubic feet.

A similar process is in the hands of an investigator in France, and it appears that the immediate possibility of distributing a much purer gas supply is presented to the gas industry.

\section{PREHISTORIC ART.}

A MELANCHOLY interest attaches to a paper A entitled "Nouvelles découvertes à Laugerie Basse: Rabots, os utilisés, œuvres d'art," by Capt. Bourlon, published in the last issue of L'Anthropologie (vol. xvii., Nos. I- 2, for January-April), because the gallant officer was killed at the opening of the war. The paper has now been edited by M. 1'Abbé Breuil. These new discoveries in this famous cave are of remarkable interest, including a fine collection of flint implements, among which the rabots, or scrapers, are of exceptional interest. We have also fine examples of work in bone, including many heads of animals engraved on this material. The engravings on stone, besides those of the normal type, display some curious variants. Of these the most remarkable are a splen-

\footnotetext{
1 Trans. Inst. Gas Eng., rgr 4, p. $2 \mathrm{r}_{3}$
}

No. 2429, VOL. 97] 